\title{
転がり疲労はく離形状に関する破壊力学的検討*
}

\author{
田 邊 裕 貴*1, 三 好 良 夫*1 \\ 高松徹*1, 林恭 年*2

\section{Fracture Mechanics Analysis for Morphologies of Flaking Failures Caused by Rolling Contact Fatigue}

\author{
Hirotaka TANABE*3, Yoshio MIYOSHI, \\ Tohru TAKAMATSU and Yasutoshi HAYASHI \\ ${ }^{* 3}$ Department of Mechanical systems Engineering, The University of Shiga Prefecture, \\ 2500 Hassaka, Hikone-shi, Shiga, 522-8533 Japan
}

\begin{abstract}
Ball-on-plate type rolling contact fatigue tests for a bearing steel JIS-SUJ 2 were carried out, and the influences of the applied load on the morphologies of the flaking failure were investigated. In order to try to describe the morphologies, stress intensity factor range $\Delta K_{\mathrm{II}}, \Delta K_{\mathrm{III}}$ for the subsurface crack subjected to cyclic loading of contact stress were estimated by using a simplified crack model. It was found that $\Delta K_{\mathrm{II}}$ for a crack with a fixed radius indicated a maximum value at a certain depth, and the depth agreed well with the maximum flaking depth obtained experimentally. The length and the width of the flaking failure were also discussed by the variations of $\Delta K_{\mathrm{II}}, \Delta K_{\mathrm{III}}$ with the change of the crack radius. The flaking width estimated from the comparison of $\Delta K_{\mathrm{III}}$ and its threshold value for fatigue crack growth was considerably close to experimental value.
\end{abstract}

Key Words : Tribology, Contact Problem, Fatigue, Fracture Mechanics, Stress Intensity Factor, Flaking Failure, Rolling Bearing

\section{1.緒言}

転がり軸受におけるはく離損傷の発生を破壊力学的 な問題として取り扱うことの重要性は, 今日では広く 認識されるところとなり，既に Paris 則を用いた転が り疲労寿命の推定なども試みられてきた ${ }^{(1)}$. しかし, 今日においても従来の寿命推定方法 ${ }^{(2)}$, すなわち Lundberg らが体系化した内部発生説 ${ }^{(3) \sim(4)}$ に基づく方法 に置き換わるような破壊力学的手法が確立されるには 至っていない. その主な理由として, はく離発生に至 るまでのき裂の発生・進展メカニズムには未だ不明な 点も多く, はく離発生を引き起すき裂の発生位置や進 展経路などの定量的評価法が確立されていないことが 挙げられる.

一方, 転がり疲労によるはく離の発生は, いわゆる 開口型ではなく，せん断型のき裂進展によるものであ るといわれている(5).これに関連し, はく離発生挙動 解明に向けた取り組みの一つとして, 最近, 高硬度, 高強度材料のモード II 疲労き裂進展特性を求めるため の新たな試験法が考案され (6) (7), 軸受銅などのマクロ き裂に関する $\mathrm{d} a / \mathrm{d} N-\Delta K_{\mathrm{II}}$ 関係が報告された．今後，

* 原稿受付 2003 年 2 月 7 日.

*1 正員, 滋賀県立大学(画522-8533 彦根市八坂町 2500).

*2 滋賀県立大学大学院 [現: (株) フジシール].

E-mail : tanabe@mech.usp.ac.jp
そのデータを有効に活用するためにも，はく離発生に 至るプロセスを明確にする必要がある，そのためには， まず発生したはく離の形状を定量的に把握し, 破壊力 学的に解釈することが必要であると思われるが，その ような研究は少ない. 従来の転がり疲労に関する破壞 力学的研究は, 二円柱間の接触問題を取り扱ったもの が多く(5),(8) (10), 玉軸受での接触状態をモデル化した 球一平板接触下での転がり疲労問題に関する研究とし

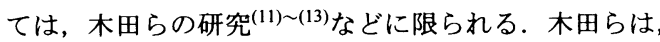
窒化ケイ素平板に人工的に予き裂を導入し, 球一平板 接触下での転がり疲労による予き裂からの疲労き裂進 展挙動を詳細に観察するとともに，はく離形状に関す る破壊力学的な検討を実施し, 観察されたはく離の寸 法が一部定量的に説明できる可能性を示した ${ }^{(13)}$. しか し，対象としたはく離が自然に発生したき裂の進展に より生じたものではないことや， はく離形状の荷重依 存性等に関する検討がなされていないことなど, 検証 すべき点も残されている.

本研究では, 種々の荷重条件下での球一平板接触転 がり疲労により発生したはく離の形状観察を行い，そ の形状を破壊力学パラメータにより定量的に説明する ことを目的とした，具体的には，はく離深さ，球転走 方向のはく離の長さ, および球転走方向に垂直な方向 の長さ（幅）について検討した. 


\section{2. 実験方法}

$2 \cdot 1$ 供試材ならびに試験片 供試材には，高炭素 クロム軸受鋼 SUJ2 の焼入れ焼戻し材を使用した。 表 面の硬さは $\mathrm{H}_{\mathrm{R}} \mathrm{C} 57$ であった. 試験片寸法は $46 \mathrm{~mm} \times$ $46 \mathrm{~mm} \times 10 \mathrm{~mm}$ で, $46 \mathrm{~mm} \times 46 \mathrm{~mm}$ の面を試験面とした. 試験面はラップ加工により鏡面に仕上げた. 試験片表 面の算術平均あらさ $R \mathrm{a}$ は $0.01 \mu \mathrm{m}$ 以下であった.

$2 \cdot 2$ 転がり疲労試験 転がり疲労試験には, 森式 転がり疲労試験機を使用した．図 1 にその模式図を示 す. 転動体には半径 $3 / 8$ インチ（約 $4.763 \mathrm{~mm}$ ）の SUJ2 球を 3 個使用した. 本試験機では, 重錘による静荷重 をこの 3 個の球を介して試験片表面に対して垂直に負 荷した状態で軸を回転させることにより，球が定軌道 円上を移動し試験片表面に転がり疲労が発生する機構 となっている. 軸回転速度は $615 \mathrm{rpm}$ とした. はく離 の発生は荷重レバーに取り付けた $\mathrm{AE}$ センサにより検 出し, はく離発生後直ちに試験機が自動停止するよう にした。転がり疲労試験は潤滑油で満たしたオイルバ ス中で行った。潤滑油にはタービン油（ML-PRF23699, 昭和シェル石油(侏)を使用した。

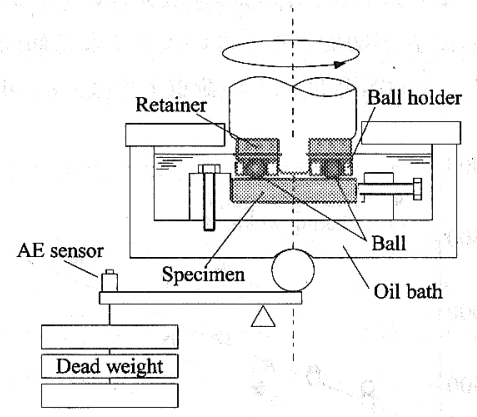

Fig.1 Schematic illustration of ball-on-plate type rolling contact fatigue test apparatus.

2.3 はく離形状の镜察本研究では, はく離形状 として, はく離の球転走方向長さの最大值（以後，は く離長さ $L$ とする), 球転走方向に垂直な方向の長さ の最大值（以後，はく離幅 $W$ とする），およびはく 離の最大樑さ $z_{\mathrm{r}}$ に着目した: $L$ と $W$ は, 走査型レーザ 顕微鏡（OSL-100，オリンパス㮫製）を用いた観察に より求めた。 $z_{\mathrm{r}}$ は，はく離の球転走方向に平行な断面 を切り出し, 研磨の後, 光学顕微鏡を用いた観察によ り求めた。図 2 には $L, W$ の観祭例を, 図 3 には $z_{\mathrm{r}}$ の 観察例を示す.

\section{3 . 応力拡大係数解析}

\section{$3 \cdot 1$ 解析モデルと座標系 転がり疲労により発生}

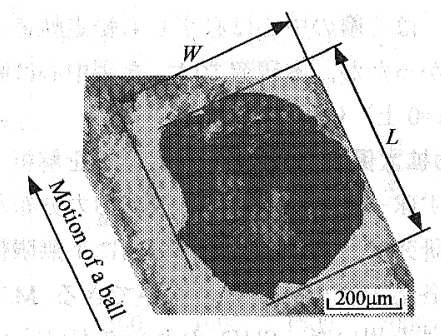

Fig.2 An example of surface observations of flaking failures $(\operatorname{Load} F=686 \mathrm{~N})$.

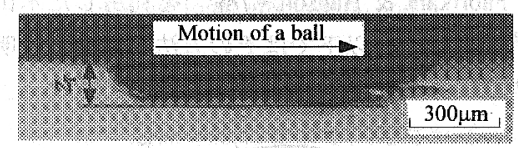

Fig.3 An example of cross-sectional observations of flaking failures (Load $F=1470 \mathrm{~N}$ ).

したはく離の縦断面観察を実施すると，図３に示すよ うな表面にほぼ平行なき裂進展の痕跡が観察されるこ とが多い(5),(9) (11)。はく離の形状は，このような試験 片内部でのき裂の進展挙動に大きく影響を受けると考 えられる ${ }^{(11)}$ ，そこで本研究では, 図4のような試験片 表面に平行な円形の内部き裂を仮定し，その梁さ $z$, 半径 $a$, 負荷荷重 $F(1$ 個の球を介して試験片に負荷 される荷重）在種々に変化させた場合の念力拡大俰数 を算出し，その結果をもとにはく離形状に関する考察 を行った。接触応力下では, 図4のようなき裂には大 きな圧縮応力が作用し開口が妨げられるため, せん断 型の進展が支配的であると考えられている(5),(9),(13). こ のため本研究では, 応力桩大係数のモード II 成分 $K_{\text {II }}$, およびモードIII成分 $K_{\text {II }}$ に注目した。

解析にあたっては，試験片表面上の接触点を原点と して, 試験片表面の球転走方向に平行な方向に $y$ 軸, 球転走方向に垂直な方向に $x$ 軸, 試騟片深さ方向に $z$ 軸をとった図 4 に示すような直交座標系を用いた。 こ こで，球は実際には定軌道円上を周回運動するが，球 は直線運動すると仮定した. はく離の表面形状観察の

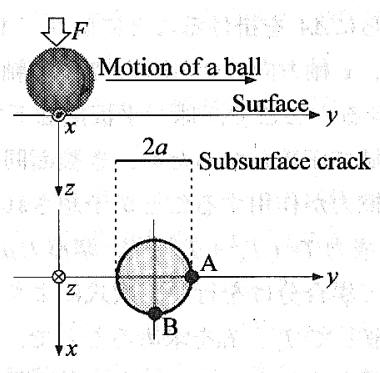

Fig.4 Crack model and coordinate system for stress intensity factor analysis. 
結果では, はく離の中心は必ずしも転走軌道の中央に 位置しなかったが, 本研究では, き裂中心は転走軌道 の中央 $(x=0$ 上) にとった.

$3 \cdot 2$ 応力拡大係数の算出 $K_{\mathrm{II}}, K_{\mathrm{III}}$ を解析するため には, まず球一平板接触下での接触応力分布が必要で ある. 本研究では, 接触応力の算出に半無限体の任意 位置での各応力成分を得ることができる M.T.Hanson の弹性解 ${ }^{(14)}$ を用いた. SUJ2 のヤング率 $E$, ポアソン 比vはそれぞれ $210 \mathrm{GPa}, 0.3$ とした。 $K_{\mathrm{II}}, K_{\mathrm{III}}$ の算出 には, Fabrikant \& Hanson の解 ${ }^{(15)}$ 利用した木田らの 方法 ${ }^{(13) を}$ 用いた。 以下ではその方法を簡単に説明する。

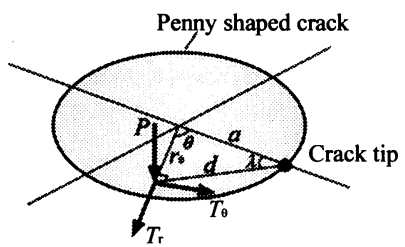

Fig.5 Crack model for Fabrikant \& Hanson's solution.

まず, Fabrikant \& Hanson の解は, 図 5 に示すよう な円形内部き裂のき裂面内のある 1 点 $(\theta, \lambda, d$, $r_{0}$ ）に集中力 $P, T_{\theta}, T_{\mathrm{r}}$ が作用したときの, き裂円周 上の任意位置での $K_{\mathrm{I}}, K_{\mathrm{II}}, K_{\mathrm{III}}$ を与える解である. こ こで， $P$ はき裂面に作用する垂直力で， $T_{\theta}, T_{\mathrm{r}}$ はそれ ぞれ周方向, 半径方向のせん断力である. 球一平板接 触下の円形内部き裂の応力拡大係数の解析手順は, 以 下の通りである. まず, 図 4 のき裂モデルの円周上に き裂先端として注目する位置を定め, そのき裂面内に 図 5 のような座標系を設ける. 例えば, 長さ方向 $(y$ 軸方向）へのき裂の進展挙動について検討する際には 図 4 中の $\mathrm{A}$ 点に, 幅方向 ( $x$ 軸方向) への進展挙動に ついて検討する際には図 4 中の B 点に, 図 5 のき裂先 端位置をそれぞれ対応させ，図 4 のき裂面中に図 5 の 座標系を設ける. 次いで, き裂面を微小面積 $\Delta A$ で分 割する. さらに, それぞれの $\Delta A$ の位置での垂直応力 $\sigma_{\mathrm{z}}$, せん断応力 $\tau_{\mathrm{xz}}, \tau_{\mathrm{yz}}$ を M.T.Hanson の弾性解により 求め, これらに $\Delta A$ を掛けることにより， $\Delta A$ に作用す る垂直力 $P, x$ 軸方向のせん断力 $T_{\mathrm{x}}, y$ 軸方向のせん 断力 $T_{\mathrm{y}}$ を得る. ここで, 球一平板接触下での $\sigma_{\mathrm{z}}$ は, 試験片の全域で圧縮となるため, き裂面同士が接触し, き裂面に摩擦力が作用することが予想される．そこで, $T_{\mathrm{x}}$ と $T_{\mathrm{y}}$ の合成力 $T=\left(T_{\mathrm{x}}^{2}+T_{\mathrm{y}}{ }^{2}\right)^{1 / 2}$ と摩擦力 $\mu P$ との大小 関係によって場合分けを行い, 次式により得られる值 $T$ をを成分分解して $T_{\mathrm{r}}, T_{\theta}$ を求めることで, き裂面接触 の影響を考慮した。ここで， $\mu$ はき裂面間の摩擦係数 を表している.

$$
T^{\prime}=\left\{\begin{array}{cc}
T-\mu P & (T \geq \mu P) \\
0 & (T<\mu P)
\end{array}\right.
$$

同様にそれぞれの $\Delta A$ に対して $P, T_{\mathrm{r}}, T_{\theta}$ を求め, こ れらを Fabrikant \& Hanson の解に代入して得られる值 をき裂面内の全ての $\Delta A$ に対して積分することで $K_{\mathrm{II}}$, $K_{\text {III }}$ を求めた. 図 4 では球が移動するモデルを示した が, 球の移動に伴う $K_{\mathrm{II}}, K_{\mathrm{III}}$ の変化は, 球を原点上に 固定し, 実際の球の移動方向と逆向きにき裂を移動さ せることで, 球とき裂の相対的な位置関係を変化させ て求めた.このとき,き裂先端を含む $\Delta A$ で $T$ 'が 0 と なる場合，すなわち，摩擦力による拘束によって，き 裂先端でのせん断変形が生じ得ないと考えられる場合 には, $K_{\text {III }}, K_{\text {III }} 0$ とした。

なお，き裂面間の摩擦係数 $\mu$ は奏測が困難であるた め, 本研究では $\mu=0,0.4,0.8$ の 3 条件を仮定した.

\section{4 . 結果と考察}

$4 \cdot 1$ はく離形状钼察結果図 6 は, はく離長さ $L$, およびはく離幅 $W$ を各はく離について測定し，これ らを荷重 $F$ で整理した結果である．図中の直線は最小 二乗法により求めた。ばらつきは大きいものの， $L$, $W$ はともに $F$ が増加するに伴い大きくなる傾向を示し た。 また， $1000 \mathrm{~N}$ 程度以下の荷重下では， $L, W$ はほ

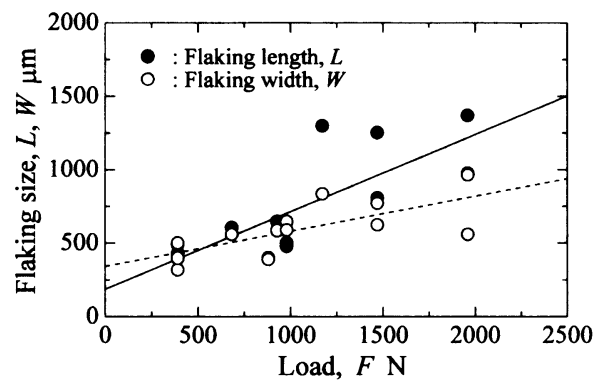

Fig.6 Relationship between load and flaking sizes obtained by surface observation.

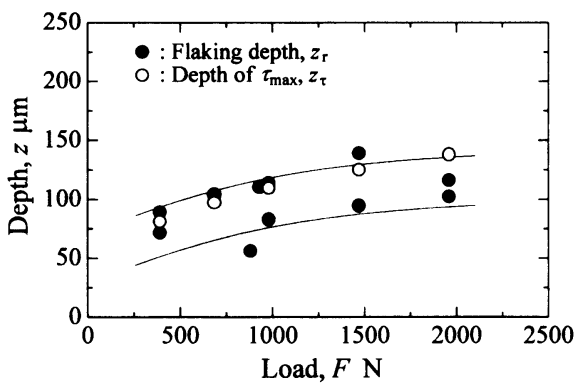

Fig.7 Flaking depth obtained by cross-sectional observation. 
ぼ等しいが，荷重が大きくなるに従い $L$ の方が大きく なる傾向が認められた. 同様の傾向は, 窒化ケイ素を 用いた木田らの研究においても確認されている(13).

一方，断面形状については，図 3 に例示したように, 多少の凹凸と傾斜を有するものの, 試験片内部の主き 裂が表面とほぼ平行に進展した様子が確認できた．他 の荷重条件下で発生したはく離の断面形状も，ほぼ同 様であった．図 7 は, 各荷重条件下で発生したはく離 の最大梁さ $z_{\mathrm{r}}$ と荷重 $F$ の関倸を示したものである．図 中には, 球の移動に伴うせん断応力 $\tau_{\mathrm{yz}}$ の振幅が最大と なる梁さ $z_{\tau}$ を併せて示した. 図 7 より, ばらつきはあ るが, 荷重の増加に伴い $z_{\mathrm{r}}$ が緩やかに増加する傾向が 認められた． $z_{\mathrm{r}}$ と $z_{\mathrm{\tau}}$ の傾向は概ね一致するが， $z_{\tau}$ は $z_{\mathrm{r}}$ のぼらつきのほほ上限に相当する深さとなった.

\section{$4 \cdot 2$ はく離深さに関する検討 はく離深さを破壊} 力学的な考察に基づき定量的に説明できるか否かを検 討するために，以下のような解析を行った．き裂先端 として図 4 のき裂モデルの A 点に注目し, まず, 深さ $z$ のき裂の球の移動に伴う応力拡大係数 $K_{\mathrm{II}}$ の変化を求 め, さらにその結果から応力拡大係数幅 $\Delta K_{\mathrm{II}}$ を求めた. ここで $\mathrm{A}$ 点では，接触応力分布の対称性により $K_{\mathrm{III}}$ は 常に 0 となる. $K_{\mathrm{II}}$ の算出方法は, $3 \cdot 3$ で示した通りで あり, $\Delta K_{\mathrm{II}}$ は球の移動に伴う $K_{\mathrm{II}}$ の変化履歴の最大値 $K_{\text {II_max }}$ と最小值 $K_{\text {II_min }}$ を用いて, 次式により求めた.

$$
\Delta K_{\mathrm{II}}=K_{\mathrm{II} \_\max }-K_{\mathrm{II} \_ \text {min }}
$$

次に，き裂深さ $z$ を種々に変化させて同様の計算を 行い, 得られた $\Delta K_{\mathrm{II}}$ とき裂深さ $z$ の関係を求めた。 そ の一例として, 荷重 $F=1470 \mathrm{~N}$, き裂半径 $a=50 \mu \mathrm{m}$ の条 件の下で摩擦係数 $\mu=0$ を仮定して得られた $\Delta K_{\mathrm{II}}$ と $z$ の 関係を図 8 に示す. 図 8 に例示されるように， $\Delta K_{\mathrm{II}}$ は ある深さで極大となる変化傾向を示すことがわかった 本研究では，その $\Delta K_{\mathrm{II}}$ が最大となるき裂深さを $z_{\mathrm{K}}$ とし， 実際のはく離哚さ $z_{\mathrm{r}}$ との関係を調べた．なお，き裂が 表面とほぼ平行に進展することが実呀的に確認されて

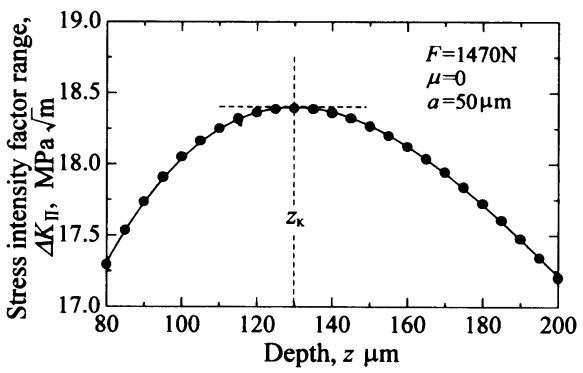

Fig.8 An example of relationship between $\Delta K_{\text {II }}$ of subsurface crack and crack depth $z$.

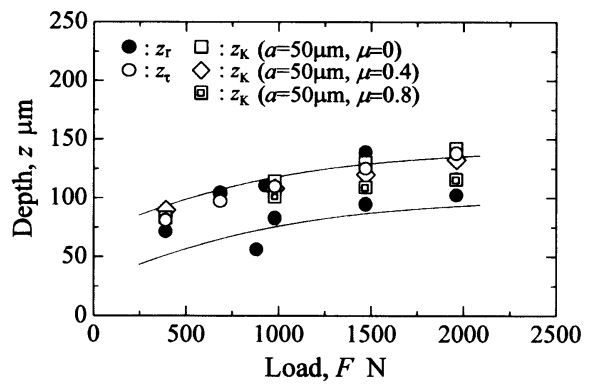

Fig.9 Comparison with flaking depth obtained by cross-sectional observation and $z_{\mathrm{K}}$.

いることから，表面とほぼ平行なき裂進展の初期段階 において，はく離深さはおおよそ決定されると考えて も差し支えないであろう，そこで，実際に観察された はく離半幅以下の比較的小さなき裂半径に着目し， $a$ として $10 \mu \mathrm{m}, 50 \mu \mathrm{m}, 100 \mu \mathrm{m}$ の 3 条件を仮定した.

図 9 は, $a=50 \mu \mathrm{m}$ のき裂について得られた, 荷重 $F$ と $z_{\mathrm{K}}$ の関係を示したものである. なお,この結果と $a=10 \mu \mathrm{m}, 100 \mu \mathrm{m}$ での結果を比較したところ， $a$ の増 加に伴い $z_{\mathrm{K}}$ が若干増加する傾向が認められたが，いず れの結果も図 9 とほぼ等しかった。 まず， $z_{\mathrm{r}}$ と $z_{\mathrm{K}}$ とを 比較すると, 両者の值および荷重の変化に伴う変化傾 向はほぼ等しい， $z_{\mathrm{K}}$ に及ぼすき裂面間の摩擦の影響に ついては, 摩擦係数 $\mu$ が大きくなるに従い $z_{\mathrm{K}}$ は小さ くなり， $z_{\mathrm{K}}$ は摩擦を考慮しない場合に比べ $z_{\mathrm{r}}$ のばらつ きの中心に近付く傾向が認められた． $z_{\tau}$ と $z_{\mathrm{K}}$ を比較す ると, 両者はほぼ等しいものの, 摩擦を考虑した場合, 比較的大きな荷重下では $z_{\mathrm{K}}$ が $z_{\tau}$ より若干小さくなる傾 向が認められた，以上の結果より，き裂面間の摩擦の 影響を考慮して $\Delta K_{\mathrm{II}}$ が最大となるき裂深さを求めるこ とで，はく離深さをある程度定量的に評価でき， $z_{\tau}$ に よる評価で得られる值よりも実際のはく離深さに近い 推測值が得られる可能性のあることが示唆された。

$4 \cdot 3$ はく離長さに関する検討 $4 \cdot 2$ と同じき裂モ デルで, き裂半径 $a$ を変化させた場合の $\Delta K_{\mathrm{II}}$ の変化挙 動を調べ，その変化挙動によりはく離長さ $L$ が説明で きるか検討した．解析は, 荷重 $F$ が $980 \mathrm{~N}, 1470 \mathrm{~N}$, $1960 \mathrm{~N}$ の 3 条件に対して行った. なお, き裂の深さは, 各荷重下で, それぞれの摩擦係数を仮定して得られた $a=50 \mu \mathrm{m}$ での $z_{\mathrm{K}}$ とした.

図 10 は, $\mu=0,0.4,0.8$ での $a$ と $\Delta K_{\mathrm{II}}$ の関係を示し たものである. 各荷重とも, $a$ が比較的小さな範囲で は, $a$ が大きくなるにつれて $\Delta K_{\mathrm{II}}$ も大きくなったが, ある值以上の $a$ では, $\Delta K_{\text {II }}$ はほぼ一定の值となった.

球一平板接触下の接触応力分布は, 接触点近傍の有 限の領域内に集中する.このため, $a$ がその領域以上 


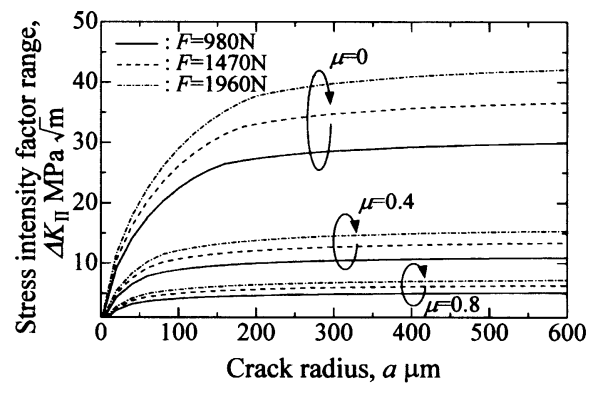

Fig.10 Variations of $\Delta K_{\text {II }}$ with the crack propagation for $y$ direction.

の大きさになっても $K_{\text {II_max }}, K_{\text {II_min }}$ には顕著な変化が 生じず, $\Delta K_{\mathrm{II}}$ が $a$ に依存しなくなるものと考えられた. ここで， $a$ の変化に対して $\Delta K_{\mathrm{II}}$ がほぼ一定となった後 の值と, 藤井ら ${ }^{(6)} に よ り$ 実験的に求められた SUJ2 鎆 のモード II 疲労き裂進展の下限界応力拡大俰数幅 $\Delta K_{\text {II } \mathrm{th}} \fallingdotseq 3 \mathrm{MPa} \sqrt{\mathrm{m}}$ とを比較すると, 解析を行った全 条件で $\Delta K_{\mathrm{II}}$ が $\Delta K_{\mathrm{II} \text { th }}$ を上回っており，いずれの条件と も, き裂の安定成長が予想される.このことから， $L$ は $\Delta K_{\mathrm{II}}$ の低下による内部き裂の停留によって決定され た寸法ではないことが推測された．はく離は，表面と ほぼ平行な内部き裂がある限界の大きさに達すること で発生する表面層の欠損の結果であるとの観察結果 ${ }^{(11)}$ がある.はく離長さを定量的に説明するためには, こ のような表面層の欠損が生じるための力学的条件等に ついて検討する必要があると考えられた.

4.4 はく離幅に関する検討 はく離幅について検 討を行うために，き裂先端として図 4 中の B 点に注目 し, その位置での $a$ の増加に伴う応力拡大係数幅の変 化を調べた. なお， B 点では， $K_{\mathrm{III}}$ も無視できない大 きさとなるため, ここでは $\Delta K_{\mathrm{II}}$ のみでなく $\Delta K_{\mathrm{III}}$ の変化 も調べた. 解析方法は, 注目するき裂先端位置が異な る以外は $4 \cdot 3$ と同様である. $\Delta K_{\mathrm{III}}$ は, $\Delta K_{\mathrm{II}}$ と同様, 球 の移動に伴う $K_{\mathrm{III}}$ の変化履歷における最大值 $K_{\text {III_max }}$ と 最小値 $K_{\text {III_min }}$ を用いて,

$$
\Delta K_{\mathrm{III}}=K_{\mathrm{III} \_\max }-K_{\mathrm{III} \_ \text {min }}
$$

により求めた. 荷重 $F$ は, $4 \cdot 3$ と同様, $980 \mathrm{~N}, 1470 \mathrm{~N}$, $1960 \mathrm{~N}$ の 3 条件を仮定した.き裂深さは各荷重下での $z_{\mathrm{K}}$ とした.

図 11 は, $a$ の増加に伴う $\Delta K_{\mathrm{II}}, \Delta K_{\mathrm{III}}$ の変化を表した ものである. $\mu$ は， $0,0.4,0.8$ の 3 条件を仮定し解析 を行ったが, 紙面の都合上, ここでは $\mu=0.4$ の結果 のみを示す. 図中の縦破線は, 各荷重でのはく離半幅 の実測値の平均を表しており，○，○印はこれらの縦

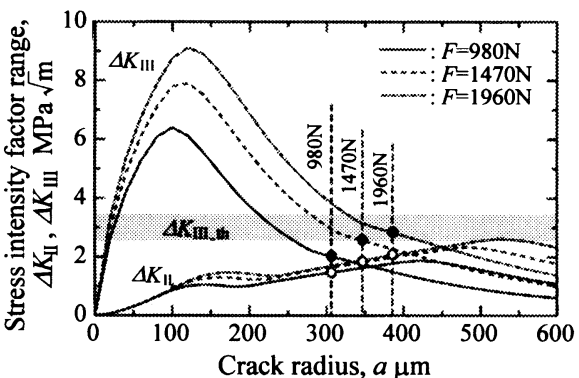

Fig.11 Variations of $\Delta K_{\mathrm{II}}$ and $\Delta K_{\mathrm{III}}$ with the crack propagation for $x$ direction $(\mu=0.4)$.

破線と, 対忘する荷重での $\Delta K_{\mathrm{II}}$ 曲線, $\Delta K_{\mathrm{III}}$ 曲線との交 点をそれぞれ表している， $\Delta K_{\mathrm{II}}, \Delta K_{\mathrm{III}}$ は，ともに $a$ の 増加に対してまず増加した後减少する. $\Delta K_{\mathrm{II}}, \Delta K_{\mathrm{III}}$ は $\mu$ の増加に伴い减少するため絶対值は異なるが, $\mu=0$, 0.8 でもこれと同様の変化傾向が 認められた. これら の傾向は, 図 10 で示した長さ方向への進展に関する $\Delta K_{\mathrm{II}}$ の変化傾向とは大きく異なっている. 長さ方向へ のき裂進展に関しては, き裂半径が増加しても, 球が き裂先端上を綝返し移動するため, その先端付近には 大きな接触応力が作用する. これに対し, 幅方向への 進展では, き裂が進展するにつれてその先端位置が球 の転走軌道から遠ざかって行くため, き裂先端付近の 接触応力は次第に減少していく．このようなき裂の進 展に伴うき裂先端付近の接触応力分布の変化傾向の相 違により, 進展方向によって応力拡大係数幅の変化傾 向に差異が生じるものと考えられる. 図 6 では, 荷重 の増加に伴いはく離形状が扁平化する傾向が認められ た. 現状では, はく離長さ $L$ がどのようにして決定さ れるかが不明であり, 荷重増加に伴うはく離形状の扁 平化を, 図 10, 図 11 の結果のみで説明することはで きないが, 両図の応力拡大係数幅の絶対值および変化 傾向の相違から判断すると, 少なくとも, はく離の幅 に比べ長さの方が大きくなり得る状況にはあると言え る.

次に, はく離幅の定量的説明の可能性について検討 した. $\Delta K_{\mathrm{II}}$ と $\Delta K_{\mathrm{III}}$ の大小関係に注目すると, 実測に より得た各荷重条件下でのはく離半幅を示す図中の綐 破線に至るまでのき裂半径では， $\Delta K_{\mathrm{III}}$ が $\Delta K_{\mathrm{II}}$ を大きく 上回っている. これは他の摩擦係数でも同様であった. このことから，内部き裂の幅方向一の進展については， $\Delta K_{\mathrm{II}}$ に比べ $\Delta K_{\mathrm{III}}$ の変化挙動をより強く反映した挙動を 示すものと推測される.そこで本研究では，まずはく 離幅評価の第一歩として, モード III の単独モードで の検討を行うことにした. なお, SUJ2 鋼のモード III の下限界応力拡大係数幅 $\Delta K_{\text {III_th }}$ が明らかではないため, 
ここでは， $\Delta K_{\mathrm{III} \_\mathrm{th}}$ が $4 \cdot 3$ で用いた $\Delta K_{\mathrm{II} \text { th }}$ に等しいと仮 定した. 図中の網掛けは, この $\Delta K_{\text {III } 九 \mathrm{~h}} に, 引$ 用元 ${ }^{(6)}$ の 実験データのばらつきを考慮し $\pm 0.5 \mathrm{MPa} \sqrt{\mathrm{m}}$ の幅を 与えて図示したものである。この網掛けで示した

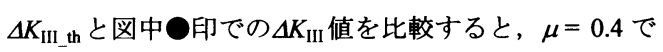
は, の印での $\Delta K_{\text {III }}$ 值は各荷重ともに $\Delta K_{\text {III_th }}$ 付近の值に

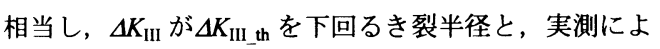
り得たはく離半幅が比較的よく対応することがわかる. $\mu=0.8$ では， $\Delta K_{\text {III }}$ は限られたき裂半径の範囲でわず かに $\Delta K_{\text {III_h }}$ を上回ることがあるものの, ほとんどのき

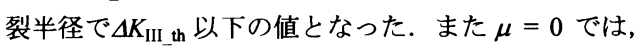
$\Delta K_{\text {III }}, \Delta K_{\text {III }}$ ともに $\Delta K_{\text {III_th }}$ に比べ十分大きく, 実験的に 得たはく離半幅に達するまでのき裂半径で, これらが $\Delta K_{\mathrm{III} \_\mathrm{th}}$ を下回ることはなかった. 以上の結果より,き 裂面間の摩擦係数が 0.4 程度であると仮定すれば,

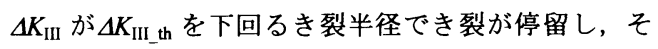
の結果としてはく離幅が決定されると考えることによ り, 実験で得られたはく離幅をある程度定量的に説明 することができた.

ただし現段階では，限られた条件の範囲内で，はく 離幅を説明できたに過ぎない，また，本研究ではモー ド III にのみ注目し, 内部き裂の幅方向への進展挙動 を考察したが, 本来はモード II も考虑に入れた混合モ ード問題として取り扱うべき問題である. 今後実験デ 一夕を抬充し, 本論文で提案した手法の有効性, 適用 範囲について検討を行うとともに，はく離幅に対する 混合モード問題としての評価・検討も行う必要がある. これらの点について, 今後さらに検討を進めたい.

\section{5 . 結論}

軸受鋼 SUJ2 の球一平板接触による転がり疲労試験 を実施し、得られたはく離の形状観察を実施した。ま た, 試験片表面と平行な円形内部き裂を解析モデルと して応力拡大係数を算出し, 応力搪大保数幅とはく離 形状との対応関係を調べた. 得られた結論は以下の通 りである.

(1) 球の移動に伴う応力拡大保数 $K_{\mathrm{II}}$ の変化幅 $\Delta K_{\mathrm{II}}$ が 最大となる深さは, 実際のはく離深さに近い值となる. また, き裂面間の摩摖を考虑して求めた $\Delta K_{\mathrm{II}}$ が最大と なる深さは, 摩擦を考虑しない場合と比べて小さくな り, 実際のはく離深さにより近づく.

(2) はく離の転走方向の長さとそれに垂直な方向の長 さは，いずれも荷重の増加に伴い大きくなるが，その 增加傾向は球転走方向の長さの方が大きくなる.

（3）球転走方向に垂直な方向では, 内部き裂の応力拡 大係数幅 $\Delta K_{\mathrm{II}}, \Delta K_{\mathrm{III}}$ は, き裂半径とともに増加し, そ
の後减少する.これに対し, 球転走方向に垂直な方向 では， $\Delta K_{\text {II }}$ はき裂半径が大きくなっても下限界応力拡 大係数幅 $\Delta K_{\text {II_th }}$ 以上の高い值を維持し，またその值は 球転走方向に垂直な方向の $\Delta K_{\mathrm{II}}, \Delta K_{\mathrm{III}}$ に比べ大きい.

(4) 球転走方向とそれに垂直な方向での内部き裂の応 力拡大係数幅の相違から判断すると, はく離の球転走 方向長さは，それに垂直な方向の長さに比べ大きくな り得る状況にある。

（5）球の転走方向に垂直な方向のはく離の長さは，き 裂半径の増加に伴う応力桩大俰数幅 $\Delta K_{\text {III }}$ の変化と下限 界応力拡大係数幅の関係から，ある程度定量的に説明 できることが示唆された.

\section{謝辞}

本研究の遂行にあたっては, 大阪大学大学院 小倉敬 二教授 (現名誉教授)，木田勝之助手から有益なご 助言を頂いた. また, 光洋精工株式会社には試験片を ご提供頂いた.ここに記して感謝の意を表す.

\section{参考文献}

(1) M.T.Hanson, L.M.Keer, ASLE Trans., 35, (1992), 451-461.

（2）JIS B 1518, 転がり軸受の動定格荷重及び定格寿命 の計算方法, (1992).

(3) G. Lundberg and A. Palmgren, Dynamic Capasity of Rolling Bearing, Acta Polytechnica, Mech. Eng. Series, 1-3, (1947).

(4) G. Lundberg and A. Palmgren, Dynamic Capasity of Rolling Bearing, Acta Polytechnica, Mech. Eng. Series, 2-4, (1952).

(5) 大塚昭夫·他 5 名, 材料, 43-484, (1994), 55-61.

（6）藤井幸生·他 2 名, 材料, 50-10, (2001), 1108-1113.

(7) 村上敬宣·他 2 名, 材料, 51-8, (2002), 918-925.

(8) Y. Murakami, et. al., ASLE Trans., 37, (1994), 445454.

（9）大塚昭夫·他 4 名，材料, 41-466, (1992), 1136-1141.

(10) 吉田彰·他 2 名, 機論, 66-641, C (2000), 275-282.

(11) 木田勝之, 小倉敬二, 材料, 48-10, (1999), 10901094.

(12) 木田勝之, 小倉敬二, 機論, 65-638, A (1999), 2113-2119.

（13）木田勝之, 小倉敬二, 機論, 66-644, A (2000), 783790.

(14) M. T. Hanson, ASME J. Tribol., 114, (1992), 606-611.

(15) Y. Murakami (Editor in Chief), Stress Intensity Factor Handbook, (1992), 434-436, Pergamon Press. 